\title{
COMPARISON OF OPTIONS FOR SUPPORTING SOCIALLY DISADVANTAGED ROMA PUPILS WITHIN THE CZECH AND SLOVAK REPUBLIC EDUCATION SYSTEM
}

\author{
Lenka Haburajová Ilavská, Jaroslav Balvín, \& Iva Staňková \\ Department of Pedagogical Sciences, Faculty of Humanities Tomas Bata University in Zlín, Štefánikova \\ 5670, 76001 Zlín (Czech Republic)
}

\begin{abstract}
Efforts at securing equal treatment in education have involved developing various compensatory procedures focusing on people in disadvantaged situations. Within the Czech and Slovak Republics, support measures are generally designed for pupils from a demotivating social environment; pupils who live in deprived districts, pupils in families who do not want to or cannot focus on their children's needs, pupils from families with long-term or severe difficult relationships, pupils living in facilities under the protection of social services or educational facilities securing institutional or protective care. A large proportion of pupils who fall within this group are from the Roma community. Thus from a long-term perspective, support measures become one of the most important tools for alleviating the future impacts of Roma marginalisation, allowing for greater chance of social participation. Systematic steps supporting the education paths of Roma children and school success are subject to great expectations, and a lot of effort and endeavour is invested in them, alongside significant funds. In order to achieve a higher level of education for socially disadvantaged Roma children, co-operation is naturally required on the one hand from the Roma themselves who should be engaged in meeting targets and implementing education objectives, while greater involvement is also essential. In seeking "equal opportunities", Czech and Slovak education policy endeavours to create such support measures and compensatory procedures which can help to balance out difference in education chances. In our research project, we have endeavoured to utilise the tool of comparative analysis in our two selected countries which have not just the common features of history, social stratification and similar development genesis, but in particular social problems and the social protection system set up. In analysing and subsequently comparing specific documents and strategies at a national level, programmes and projects, we have endeavoured to find common and different integration tools which the education and political system in both countries are striving to achieve, and which through implementing they aim to balance out the chances for disadvantaged Roma pupils, thus increasing their chances for professional and social participation within society.
\end{abstract}

Keywords: Roma minority, social policy, education.

\section{Introduction}

The Roma are the largest and most vulnerable minority living in the territory of Europe. Their population is estimated at $6-12$ million, two thirds of whom are living in Central and Eastern Europe. The Roma form the second largest ethnic minority in Slovakia, even if according to some sources, they are the largest minority (Šuvada, 2015). In the last population census of 2011, only 105,738 Roma admitted that they belong to the Roma minority, which is about two percent of the total population of the Slovak Republic. The population census is based on the voluntary identification of the citizens with one or the other nationality or ethnic group. Most of the Roma, perhaps due to ignorance or fear of subsequent discrimination do not voluntarily admit their Roma ethnicity and opt for another nationality category, citizens of Slovakia and Hungary (Vaňo, 2001). Upon application of the principle of, so-called, "attributed ethnicity", the structure of the Slovak population is diametrically different. In consequence of this, the outputs of the statistical estimates and sociological mapping differ while according to some sources, about half a million Roma live in Slovakia (Šuvada, 2015). The Atlas of Roma Communities 2013 (Atlas rómskych komunít 2013) (Mušinka et al., 2014) provides a qualified estimate of the number of Roma living in the territory of Slovakia at the level of 403,000 people, which is approximately 7.4 percent of the total population. 
Similar problems exist in the Czech Republic concerning the citizens' public declaration of their Roma ethnicity. Nevertheless, according to the latest sources, The Report on the status of the Roma minority in the Czech Republic for 2017, the Roma are the largest ethnic minority living in the Czech Republic. The qualified estimates of the coordinators for Roma affairs state that in 2017 the Roma population in the territory of the Czech Republic was 240,300 people, which is $2.2 \%$ of the total population of the Czech Republic. In terms of the socio-economic status of the Roma families, we can differentiate the social position of the Roma into two different groups. The first is the group of Roma who are integrated in the society and the second is the group of Roma who are socially isolated or are endangered by social isolation. For instance, concerning the Czech Republic, polemics exist to the effect that the ratio of the groups is about fifty-fifty.

Table 1. Comparative demographic development of the Roma in the Czech Republic and the Slovak Republic, 2011.

\begin{tabular}{|l|l|l|}
\hline Age group & $\begin{array}{l}\text { Roma population in the Czech } \\
\text { Republic }\end{array}$ & $\begin{array}{l}\text { Roma population } \\
\text { in the Slovak Republic }\end{array}$ \\
\hline 0 to 14 & $23.2 \%$ & $39.4 \%$ \\
\hline $15-64$ & $73.6 \%$ & $58.5 \%$ \\
\hline $65+$ & $3.2 \%$ & $2.1 \%$ \\
\hline
\end{tabular}

Source: Adjusted according to Šprocha 2014, p. 21, www.czso.cz

The educational level of the Roma in Europe is historically very low and to date, the difference in the education of the Roma and the rest of the population was not overcome mainly in the countries of the former, so-called, Eastern Bloc. Although education was a key element of the assimilation campaign in the period of the Socialist era of these countries and was seen as a tool of political and economic socialization, which would simplify the integration of the Roma, mainly in terms of employment. Nevertheless, in spite of these efforts, the foundation was laid for inequality in education, especially in terms of quality because many Roma were directed to schools outside the main educational stream system. The politicians in all the Member States of the EU are making an effort to solve this situation, nevertheless, the situations require the comprehensive and cooperative approach of many stakeholders and solution of the issue of the education of Roma students seems to be a long process.

\section{Objectives/methods}

The objective of the research was to identify the differences in support provided in the education of the Roma in the Slovak Republic and the Czech Republic. We focused on the specification of parameters in the area of support for the education of Roma students in the Slovak Republic and the Czech Republic. The main objective of the research is to map the issue of the education of Roma students in the Slovak Republic and the Czech Republic from the viewpoint of the support measures. The particular targets were:

$\checkmark$ Map the current status and situation of the Roma in Slovakia and in the Czech Republic in the legislative documents.

$\checkmark$ Identify the common features of the support measures within the scope of the educational policies.

$\checkmark$ Capture the differences in support provided in the education of the Roma in the Slovak Republic and the Czech Republic.

We used the qualitative research methodology with application of multiple methods such as comparative analysis of documents, literature, action plans and legislative norms.

Table 2. Compared documents.

\begin{tabular}{|l|l|}
\hline Czech Republic & Slovak Republic \\
\hline $\begin{array}{l}\text { Principles of the Long-term Roma Integration Concept up to } \\
2025\end{array}$ & $\begin{array}{l}\text { Comprehensive program for development of Roma Settlements } \\
2002-2006\end{array}$ \\
\hline Roma Integration Strategy up to 2020 & $\begin{array}{l}\text { Government policy concept of the SR in the integration of } \\
\text { Roma communities 2006 }\end{array}$ \\
\hline $\begin{array}{l}\text { The development of Roma education in the Czech Republic, } \\
\begin{array}{l}\text { Evaluation of the situation in the Czech Republic and the } \\
\text { Strategic Guideline of the Roma Educational Fund, 2007 }\end{array}\end{array}$ & $\begin{array}{l}\text { The medium-term concept of the development of the Roma } \\
\text { national minority in the Slovak Republic - SOLIDARITY- } \\
\text { INTEGRITA-INKLUZIA 2008-2013) }\end{array}$ \\
\hline $\begin{array}{l}\text { Concept (project) of timely care for children from } \\
\text { the socio-culturally disadvantaged environment in the field of } \\
\text { education, 2005 }\end{array}$ & $\begin{array}{l}\text { The actions plans of the strategy of the Slovak Republic for } \\
\text { integration of the Roma up to 2020 }\end{array}$ \\
\hline Action plan of inclusive education for the period 2016-2018 & Concept of integrated education in the Slovak Republic \\
\hline
\end{tabular}




\begin{tabular}{|c|c|}
\hline $\begin{array}{l}\text { Strategy of the educational policy of the Czech Republic up to } \\
2030+\end{array}$ & $\begin{array}{llllll}\text { National Programme for Development of Training and } \\
\text { Education 2018-2027 }\end{array}$ \\
\hline $\begin{array}{l}\text { Action Plan of measures for the education of Roma children, } \\
\text { pupils, students for the period 2015-2017 }\end{array}$ & 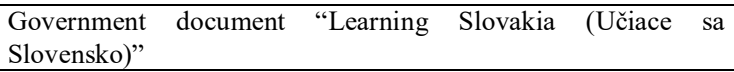 \\
\hline $\begin{array}{l}\text { Report on the fulfilment of the Decade of Roma Inclusion } \\
2005-2015\end{array}$ & $\begin{array}{l}\text { Step by Step and the Programme of Education and Social } \\
\text { Justice }\end{array}$ \\
\hline Educational situation reports (Zprávy o stavu školství) & Educational situation reports (Správy o stave školstva) \\
\hline $\begin{array}{l}\text { Decree No. 27/2016 Coll., on education of pupils with special } \\
\text { educational requirements and gifted pupils, as amended under } \\
\text { Decree No. 270/2017 Coll., Decree No. } 416 / 2017 \text { Coll., and } \\
\text { Decree No. } 244 / 2018 \text { Coll. }\end{array}$ & $\begin{array}{l}\text { Act No. 383/2013 Coll., on contributions upon birth of a child } \\
\text { and contribution for more children born at the same time }\end{array}$ \\
\hline Act No. 117/1995 Coll., Act on State Social Care & Act No. 561/2008 Coll., on children's social allowances \\
\hline & $\begin{array}{l}\text { Act No. 627/2005 Coll., on contributions to support of } \\
\text { additional care for children }\end{array}$ \\
\hline Act No. 108/2006 Coll. Act on social services & Act No. 448/2008 Coll., on social services \\
\hline $\begin{array}{l}\text { Act No. 359/1999 Coll., Act on the social and legal protection } \\
\text { of children }\end{array}$ & $\begin{array}{l}\text { Act No. 305/2005 Coll., on the socio-legal protection of } \\
\text { children and social guardianship }\end{array}$ \\
\hline $\begin{array}{l}\text { Act No. 561/2004 Coll., Act on pre-school, primary, } \\
\text { secondary, higher vocational and other education (The School } \\
\text { Act) }\end{array}$ & $\begin{array}{l}\text { Act No. 596/2003 on the State Administration in Education and } \\
\text { Educational Self-Government }\end{array}$ \\
\hline & Act No. 544/2010 Coll., on subsidies for food \\
\hline
\end{tabular}

\section{Results}

Below, we state the comparison of the most significant measures for support of the education Roma children in both countries:

Table 3. Measures for support of the education Roma children - common features.

\begin{tabular}{|l|l|}
\hline Czech Republic & Slovak Republic \\
\hline Special educationalist in the schools & Special educationalist in the schools \\
\hline Assistant educationalist & Assistant teacher \\
\hline Zero year & Zero year \\
\hline Social scholarships & Social scholarships \\
\hline Merit scholarships & Merit scholarships \\
\hline Community Centres & Community Centres \\
\hline Assessment and testing of educational capacity & Assessment and testing of educational capacity \\
\hline $\begin{array}{l}\text { Grants under the project - School lunch for children from } \\
\text { deprived families }\end{array}$ & Grants for free lunch in schools \\
\hline Contribution to school aids & Grant for purchase of school aids \\
\hline
\end{tabular}

Table 4. Measures for support of the education Roma children-differences.

\begin{tabular}{|l|l|}
\hline Czech Republic & Slovak Republic \\
\hline Absence of the position of a social educationalist & Special educationalist in the school \\
\hline Obligatory pre-school education & Pre-primary school education of children is not obligatory \\
\hline Child allowance depending on the size of income & $\begin{array}{l}\text { Family allowances for all children without testing on the } \\
\text { revenues of the parents }\end{array}$ \\
\hline $\begin{array}{l}75 \text { percent discount on the railway and bus transport fares for } \\
\text { students up to age of 26 }\end{array}$ & Free railway transport \\
\hline
\end{tabular}

The Roma are recognised as a national minority in the Constitution of the Slovak Republic, Czech Republic and international documents of the Council of Europe ratified by the Slovak Republic and the Czech Republic guarantee the right to education in the mother tongue. In the case of the Roma minority, however, the exercise of this right was complicated by the fact that the Roma language was not standardized until 2008. A further persisting problem remains the acute deficiency of qualified teachers of the given subjects and deficiency of teaching texts and materials. The situation is the same in the Czech Republic. The greater majority of the Roma population is for this reason educated in Slovak and Czech schools, which do not teach the Roma language and literature. In the education of these pupils, it is necessary to realise that they are members of the socially weakest and backward classes of the population - in the process, the term "pupils from the Marginalized Roma Communities (hereinafter "MRC") is used, or pupils from the "Socially Disadvantaged Environment (hereinafter "SDE")". The problem continues to be the unclear use of this definition in practice. A similar intent of this institute was for a Roma assistant teacher to work with the pupils from the SDE/MRC, at best from the given community that is conversant with the Roma language and local dialect. Currently, only a minimum number of the assistant teachers (pedagogical assistants) master the Roma language.

In the rest of the years, the instruction of obligatory pre-school education was discussed in Slovakia, mainly in relation to ensuring the school attendance of Roma children. One of the targets of the Draft National Training and Development Programme known as "Learning Slovakia" is guaranteed 
pre-primary school education for all children from the age of 3. Pre-primary school education shall be obligatory from the age of 5 and shall be free-of-charge. This measure was implemented on the basis of the good experience of other European countries. In an effort to ensure the participation of all children in pre-school education, most of the European countries made pre-school education free-of-charge and obligatory at least for one year prior to entering primary school (Austria, Bulgaria, Latvia and Switzerland) (European Commission/Eurydice/Eurostat 2014, 40). The Czech Republic introduced obligatory pre-school education from the age of 5 in September 2017 (European Commission 2016).

Concerning the Roma children, the problem is also in the inadequate network of nursery schools in the localities where they live. In comparison with other countries, we rank last in this area and this measure seems to be fundamental within the framework of support for education.

The second significant institution, which should help the pupils from the SDE, is the so-called "Zero Year". The minimum number of pupils in the zero-year class is 8 and the maximum is 16. For each pupil assigned to the zero year, the school shall receive $200 \%$ of the normative. For many teachers, this is a significant and sensible tool for the pupils from the SDE to catch-up in the social and cognitive areas with children growing up in a normal environment so as for them to enter the "educational mainstream" as soon as possible. The pupils from the socially disadvantaged environment are entitled to support from the Ministry of Labour of the Slovak Republic in the form of a grant for meals, aids and also a motivational allowance for the child's regular school attendance. (Regional research of marginalize Roma, 2011, UNDP/World Bank)

It is further necessary to support study at secondary school and universities which is successful only thanks to scholarships, which may be merit or social in character. Part from this, the State supports the education of Roma children also by means of recurrent allowances such as family allowances, one-off grants for purchase of school aids, free lunch. Apart from this, the support of community social services is being promoted - community centres, which focus on the reflection of the opinions or needs of the clients. The involvement of the community in any development processes is a generally accepted criterion and the condition for participation with objective to involve the participants in the identification and solution of social problems and thus improve the quality of the life of individuals and the society. Involvement of the family in the education of small children is however acknowledged as a fundamental right and duty (OECD 2012, 2).

\section{Conclusions}

The Slovak educational system shall in future require comprehensive reform, which shall be based mainly on:

$>$ Rapid increase of the training of children from the MRC from the age of 3 in nursery schools - significant investments in pre-primary training of children and education of children from the MRC together with support of the programme for child care at an early age;

$>$ Processing and implementation of the desegregation standard in the education (together with the indicators and subsequent monitoring of segregation), which should respect the principle of social interaction of the Roma and non-Roma children at the highest possible quality of education and achievement of the learning outcomes, with the exception of the Roma national school system and localities with a majority representation of the Roma population (the condition for this, however, remains the observance of the principle of top quality in education and achievement of the learning outcomes);

$>$ Processing of specific models of educational inclusion for various situations and target groups with the ambition to create a general model of an inclusive school. During the creation of the inclusive educational environment, it is necessary as a priority to take into consideration the personalities of the pupils who come from the environment of the marginalized Roma communities. A significant document is the National Training and Education Development Programme, which proposes the modernisation of the methods applied in the battle against negative social phenomena (e.g. with prejudices of racist, xenophobic and discriminatory features in the school environment) based on modern concepts, such as, training for global citizenship. Global citizenship is a significant component of the UN Agenda 2030. The Ministry of Education of the Slovak Republic is the coordinator of training for global citizenship within the framework of the national programme titled "Agenda 2030" and development of the given methodology.

Concerning the Czech Republic, a problem that is frequently mentioned in connection with the education of Roma children is the absence of the teaching of Roma History and Culture within the scope of the syllabus at primary and secondary school, whereas it is just the knowledge of Roma culture and history that is the basis for merging of the majority society with the Roma minority. According to the Roma Minority Status Report in the Czech Republic for 2017, the teaching of Roma culture and history with special regard to the holocaust period, which at international level in 2017 disturbed even the Ad hoc Committee of the Council of Europe for Roma Affairs with the outcome that this topic is not adequately 
reflected in the European countries. A further problem is lack of an adequate number of Roma assistants in the schools. These assistants are also missing from schools with a higher ratio of Roma pupils. At the same time, communication and cooperation on the part of the school - pupil - parents - other institutions is poor. It is mainly necessary within the scope of communication with the parents to place emphasis on emphasis of the importance of education for the future of their children. Efforts at balancing of the chances of the Roma pupils with the chances of the pupils who come from the majority society are being made in the educational systems of both countries through various integration tools. The support measures are generally intended for the pupils from a highly uninspiring social environment, pupils who live in, so-called, deprived areas, pupils in families that do not want or cannot pay attention to the needs of children, pupils from families with long-term or seriously disrupted relationships, pupils located in social protection and school facilities for the purpose of institutional or protective care. In all, the objectives of all concepts in the area of education are focused on the support of the educational success of socially disadvantaged Roma children in the main educational stream, for support upon achievement of qualifications and hence the creation of conditions for better engagement in the labour market, whereas the primary vision is:

$>$ for the Roma children to achieve the same average education as non-Roma children,

$>$ for the educational structure of the Roma to be close to the educational structure of the non-Roma population,

$>$ for the Roma children not to be "over represented" in the educational programmes with lower educational ambitions

$>$ for the gifted (talented) Roma children to be supported by the State and society in their ambitions to achieve higher education.

On the basis of the above-stated major visions, we subsequently earmark further proposals and measures for adoption:

$\checkmark$ Support of informal education - school clubs combined with tutoring

$\checkmark$ Study materials in the Roma language

$\checkmark$ Alternative forms of teaching

$\checkmark$ Development of community social services - field staff to work with the families

$\checkmark$ Provision of free capacity in schools, construction of nursery schools in the communities

$\checkmark$ Provision of supervised bus transport to school free-of-charge

\section{References}

Government of the Czech Republic. Roma minority status report 2017. From: https://www.vlada.cz/assets/ppov/zalezitosti-romske-komunity/dokumenty/Zprava-o-stavuromske-mensiny-2017.pdf

Mušinka, A. D., Škobla, J. Hurrle, K. Matlovičová, and J. Kling. 2014. Atlas of Roma Communities in the Slovak Republic 2013 (Atlas rómskych komunít na Slovensku 2013). Bratislava, UNDP.

OECD. 2012. Starting Strong III. A Quality Toolbox for Early Childhood and Care. Paris: OECD Publishing. OECD. 2013. "How Do Early Childhood Education and Care (starostlivost' a vzdelávanie v ranom detstve) Policies, Systems and Quality Vary across OECD Countries?” Education Indicators in Focus 11. http://dx.doi.org/10.1787/5k49czkz4bq2-en

Šprocha, B., 2014. Reproduction of the Roma population in Slovakia and prognosis of population development. Bratislava: INFOSTAT. From: http://www.infostat.sk/vdc/pdf/Romovia.pdf

Šuvada, M., 2015. Roma in the Slovak cities. Bratislava: POMS. http://suvada.sk/romovia-v slovenskychmestach.pdfMušinka, A., D. Škobla, J. Hurrle, K. Matlovičová, and J. Kling. 2014.

UNDP. 2012. Report on the Living Conditions of the Roma Household in Slovakia 2010. www.eurasia. From: https://www.undp.org/content/dam/rbec/docs/Report-on-the-living-conditions-of-Romahouseholds-in-Slovakia-2010.pdf

Vaňo, B., 2001. "Estimate of the number of Roma in the Slovak Republic (Odhad počtu Rómov na Slovensku).” Sociológia 33(5): 509-512., M. 2015. Roma in the Slovak cities. Bratislava: POMS.

World Bank. 2012. Diagnostics and Policy Advice on the Integration of Roma in the Slovak Republic. From: http://documents.worldbank.org/curated/en/570461468303056342/pdf/729850ESW0Whit0port09 $\%$ 20Sept20120Final.pdf

World Bank. 2015. Inclusion Today, Prosperity Tomorrow: The Benefits of Early Childhood Development for Roma Children. www.worldbank.org/en/news/feature/2015/08/26/inclusiontodayprosperity-tomorrow-benefits-of-early-childhood-development-for-roma-children World Bank. 2016. Being Fair, Faring Better: Promoting Equality of Opportunity for Marginalized Roma. Washington, DC: 